\title{
Animeldelse:
}

\section{Der var engang \\ en krig - i Vietnam}

E Erik Beukel

Vi har fået et nyttigt mammutværk på dansk, som på over 500 sider giver en udførlig historisk fremstilling af Vietnamkrigen. Centralt står gennemgangen af, hvorledes USA først eskalerede deltagelsen i krigen, få år senere deeskalerede og til sidst gav helt op.

Bjerre-Poulsen, Niels: Vietnamkrigen. En International Historie 1945-1975. Gyldendal, 2015. 580 s.

Historien om Vietnamkrigen kan begynde mange steder: ved Frankrigs erobring af Indokina i sidste halvdel af det 19. århundrede som en del af 'mission civilisatrice,', nationalisters og kommunisters krig mod koloniherredømmet, angrebet på franske garnisoner i Hanoi i 1946 eller Frankrigs nederlag ved Dien Ben Phu i 1954. Derefter overtog USA gradvist krigen, og i 1960'erne blev den amerikanske krigsdeltagelse stærkt udvidet. Vigtige beslutninger blev taget i Hanoi og Washington.

I 1959 havde Hanoi under ledelse af Nordvietnams kommunistparti givet grønt lys for, hvad de kaldte 'revolutionær krig' i Sydvietnam. Det skete efter øn-

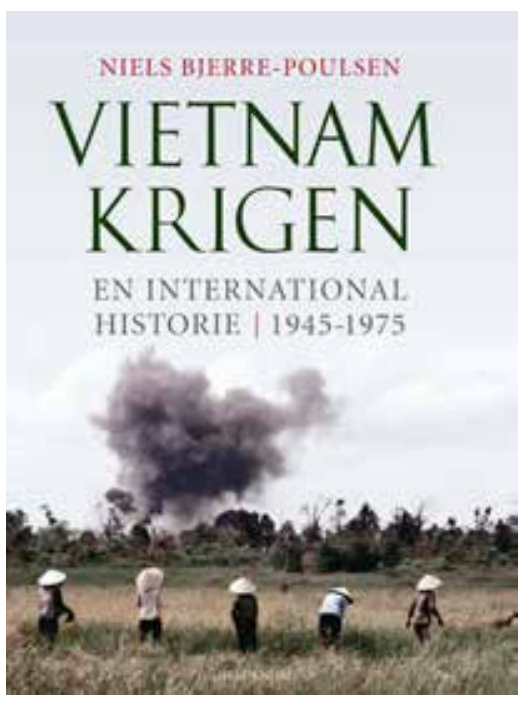

ske fra lederne i Sydvietnam af Viet Minh (Forbundet for Vietnams Uafhængighed), der var oprettet i 1941 af Ho Chi Minh og fungerede som frontorganisation for kommunistpartiet. Nordvietnam var som Den Demokratiske Republik Vietnam blevet udråbt som selvstændig stat i 1945, der i begyndelsen blev støttet af USA i forlængelse af krigen mod Japan og amerikanske uafhængighedsidealer.

Bjerre-Poulsen skildrer, hvorledes kri-

Erik Beukel er dr. scient.pol. og tidligere seniorforsker på Dansk Institut for Internationale Studier. Han har skrevet og bidraget til adskillige bøger. 
gen mod kolonimagten styrkede kommunistpartiets dominerende rolle i den nordlige del af landet, hvor der blev skabt en politistat, og det vendte hurtigt den amerikanske holdning fra at være præget af anti-kolonialisme til helt at være domineret af anti-kommunisme. Efter den midlertidige deling af Vietnam ved Genèvekonferencen i 1954 havde også Diem-regeringen i Sydvietnam taget skridt hen imod diktaturet.

For at bekæmpe Diem-regimet fandt lederne i Hanoi det hensigtsmæssigt at danne en såkaldt folkefront, og i 1960 oprettedes Den Nationale Befrielsesfront, FNL (Viet Conq), hvis partisaner - med forfatterens udtryk - "myrdede målrettet både de værste og de bedste embedsmænd i mange af sydens landsbyer".

På samme tid blev John F. Kennedy valgt som en ung og energisk præsident til at efterfølge Eisenhower-administration, og det gav den amerikanske Vietnampolitik ny dynamik. Nu skulle der vises handlekraft.

\section{USA: fra skråsikkerhed til tragedie}

Kennedy-administrationen havde en klippefast tro på, at ingen udenrigspolitiske problemer oversteg dens evner, og Vietnam blev hurtigt det rette sted til at genvinde initiativet i den kolde krig. Blandt Kennedys mange 'kloge hoveder' blev ikke mindst forsvarsminister McNamara symbolet på den nye administrations skråsikkerhed, og den første sætning i bogen omtaler da også McNamaras død som 93 årig i 2009.

Kennedys stolte ord i tiltrædelsestalen om, at USA skulle være parat til at "betale enhver pris, bære enhver byrde, møde enhver besværlighed, støtte enhver ven, modsætte sig enhver fjende, for at sikre frihedens overlevelse og succes" var et utvetydigt signal til venner og fjender. Et par uger før havde Khrusitjov erklæret sin støtte til nationale befrielseskrige, og den nye administration blev fascineret af 'counterinsurgency'. For Washington var Hanoi og enhver oprørsbevægelse, der påkaldte sig navnet 'kommunistisk' et surrogat for Beijing og Moskva og en brik i den kolde krig, og det gav ingen mening at påstå, at kommunistiske regeringer kunne være fjendtlige over for hinanden.

Vicepræsident Johnson blev sendt på en moralforstærkende mission til Sydvietnam, hvor han udnævnte præsident Diem til 'the Winston Churchill of today'. Fasthed i Indokina var nødvendig for at styrke USA's troværdighed i Europa, og når europæiske ledere ikke delte opfattelsen af Vietnamkonfliktens globale betydning, blev de blankt afvist: USA var et exceptionelt land uden europæernes mørke fortid som kolonimagter.

Men samtidig var Kennedy ambivalent, som da senator Mansfield efter en rundrejse i Sydvietnam rapporterede til præsidenten, at USA var på vej ud i kviksand, og at den vægt, den amerikanske regering tildelte landet, langt oversteg dets reelle betydning. Efter at have læst rapporten betroede Kennedy en nær rådgiver, at han både var vred på Mansfield for kritikken og vred på sig selv, fordi han tog sig i at være enig med senatoren.

Da Kennedy tiltrådte i januar 1961 var der 600 amerikanske militærrådgivere i Sydvietnam, og da præsidenten blev myrdet i november 1963, var tallet 16,300. Forslag om at sende kamptropper blev foreløbig afvist af præsidenten, men USA's prestige som supermagt allerede var på spil i Indokina.

Efter præsident Johnsons valgsejr i 1964 kom der fart på USA's krigsdeltagelse. De første bombninger af Nordvietnam fandt 
sted i 1965, og de første amerikanske kamptropper gik i land i Sydvietnam samme år. Potentielle bombemål som dæmninger og vandingssystemer, som kunne have lammet Nordvietnam, undgik man dog.

Det samme gjaldt bombemål nær grænsen til Kina og havnen i Haiphong, hvor sovjetiske skibe kunne være blevet ramt. Krigen i Vietnam skulle vise USA's evne til at føre begrænset krig mod kommunismen uden, at de to kommunistiske stormagter blev direkte involveret.

Samtidig slog præsidenten på München-analogien: Eftergivenhed skærpede aggressorers appetit, og han delte en grundlæggende amerikansk opfattelse af, at når de fik valget, ville alle folk i verden vælge frihed og demokrati, som USA havde gjort det i slutningen af det 18. århundrede.

Til forskel fra Kennedy var den hjemlige dagsorden nok så vigtig for Johnson, og Republikanerne skulle ikke have lov til at ødelægge hans reformprogram - the Great Society - med en påstand om, at han var præsidenten, der 'tabte' Vietnam, som de havde ødelagt Truman 15 år tidligere med beskyldningen om, at Truman 'tabte' Kina.

\section{Johnsons tvivl}

Bag lukkede døre var Johnson naget af tvivl, men han havde en oprigtig tro på, at de sydvietnamesiske ledere kunne opdrages til at opføre sig på demokratisk vis og blev stærkt irriteret, når en prominent journalist som Walter Lippmann tidligt satte spørgsmålstegn ved denne tro. Internt $\mathrm{i}$ administrationen var der enkelte kritikere, der opfordrede Johnson til at ændre kurs, ikke mindst den europæisk orienterede viceudenrigsminister George Ball, hvis forudsigelser allerede under
Kennedy om USA's uoverskuelige problemer i Sydøstasien blev profetiske.

Det samme gjaldt analyser fra CIA, der gang på gang betvivlede værdien af bombningerne i forsøget på at bremse Nordvietnams støtte til Viet Conq. Flere interne analyser konkluderede også, at konflikten Vietnam ikke i sig selv var vigtig for USA's sikkerhed, men kun var blevet det fordi den amerikanske regering igen og igen havde sagt det.

I foråret 1968 begyndte stemningen at vende efter en række voldsomme begivenheder i Sydvietnam. Nordvietnams og FNL's Tet-offensiv var særdeles brutal og førte til massakrer mod civile, bl.a. i den tidligere kongeby Hue.

I Washington var den afgørende effekt af offensiven, at den viste, at den store amerikanske militærindsats (bl.a. 536,000 tropper) ikke havde drænet fjendens vilje til fortsat at kæmpe, og at sejren ikke var lige om hjørnet, som hævdet gentagne gange. Tv-billeder af Saigons politichef, der henrettede en FNL-partisan på åben gade, forråelsen af amerikanske officerer og soldater og My Lai massakren, der forgæves blev søgt hemmeligholdt for den politiske og militære ledelse i Washington, var med til at undergrave opfattelsen af Sydvietnam som en del af Den Frie Verden.

På få måneder vendte holdningerne ikke blot i den amerikanske offentlighed, men også blandt mange traditionelle høge i det udenrigspolitiske establishment. Den nye forsvarsminister, Clark Clifford, kunne ikke længere se en mening med USA's krigsindsats og mente efter en rejse til Vietnams nabolande, at dominoeffekten var overvurderet. En særlig rådgivergruppe af 'Vise Mænd', som tidligere havde tilskyndet Johnson til at optrappe krigsindsatsen, chokerede præsidenten, da de 
fortalte ham, at tiden var inde til at afvikle det amerikanske militære engagement $\mathrm{i}$ Vietnam.

Efter 'Vietnaminisering' af krigen og gradvis tilbagetrækning, blev de sidste amerikanere evakueret med helikopter fra den amerikanske ambassades tag $i$ april 1975. To timer senere indtog nordvietnamesiske kampvogne præsidentpaladset, og Saigon faldt. Økonomisk armod og totalitært styre fulgte i Sydvietnam, hvor en form for diktatur havde eksisteret gennem hele historien. 300.000 embedsmænd og officerer blev sendt på 'genopdragelse', og i løbet af de første to årtier efter Vietnams genforening forlod mellem 1,4 og 2 millioner mennesker landet.

Skråsikkerhed var via hybris blevet til tragedie for Sydvietnam og for USA. Men ingen andre lande overgav sig til kommunistisk styre efter Saigons fald.

\section{'Vietnam' - et lærestykke?}

Som Bjerre-Poulsen skriver, er 'Vietnam' i USA blevet et begreb, som forbindes med bristede illusioner, national splittelse, død og nederlag. Alle er enige 'aldrig et Vietnam igen'. Men derefter hører enigheden op.

Forsvaret af Sydvietnam blev set som en afgørende del af den kolde krig, og en nestor blandt vestlige koldkrigsforskere, John Lewis Gaddis, har betegnet den lange og kostbare militære indsats for at redde Sydvietnam som USA's største fejl i den kolde krig. Mange historikere med speciale i Vietnamkrigen er enige i, at Washington gik bersærk i en absurd eskalering af krigen, der blev udkæmpet for hovedløse mål.

Modsat mener en revisionistisk skole, at USA's militære engagement i Indokina var en ædel mission, hvor de snærende begrænsninger på det amerikanske mili- tær hindrede sejren. I USA er 'Vietnam' stadig et blødende sår, som mange helst vil glemme. Men såret bløder uvægerligt op igen. Da McNamara i 1995 udgav sine erindringer, In Retrospect. The Tragedy and Lessons of Vietnam, vakte det voldsom diskussion, at han erklærede "vi tog fejl ... vi tog frygteligt meget fejl”, og bogen er fyldt med eksempler på USA’s fejltagelser, bl.a. dyb uvidenhed om Vietnams historie, kultur og politik.

Siden 1965 havde McNamara i stigende grad været i tvivl om værdien af den amerikanske krigsindsats, og som Bjerre-Poulsen træffende skriver "ført en form for moralsk dobbeltbogholderi”, når han fortalte offentligheden om fremskridt over forventning, mens hans notater til præsidenten blev mere og mere pessimistiske.

Bjerre-Poulsens værk giver anledning til nogle overvejelser om en særlig idepolitisk tradition i USA med rod i landets oprindelse og udvikling som indvandrersamfund: grænseløs demokratisk ide(al) isme. Kernen er troen på USA's politiske ingeniørkunst for at fremme demokrati og frihed over hele kloden ved hjælp af amerikansk teknologi, udviklingsprogrammer, goodwill, nation-building og militær magt.

Andre udenrigspolitiske traditioner i USA advarer mod denne tænkning og påpeger, at den ofte resulterer i et tunnelsyn på konflikter, hvor historiske og geografiske forhold ignoreres med katastrofale konsekvenser. I Vietnam prøvede amerikanerne flere af redskaberne i den politiske værktøjskasse, men efter midten af 1960'erne var militær magtanvendelse altdominerende.

Hvad er da læren af USA's rolle i Vietnamkrigen? Først og fremmest at heller ikke USA skaber sin egen udenrigspolitiske virkelighed. Som fremhævet af 'kloge 
hoveder' i den righoldige amerikanske debat, er udenrigspolitiske handlingers etik et spørgsmål om konsekvenser og mindre om motiver og gode hensigter eller selvgodhed. Omvendt følger at den blotte påvisning af denne tankegang i Washington ikke er tilstrækkelig for at afvise en militær indsats, men gentagne henvisninger til demokratiske idealer kan være en indikator på, at der mangler noget fundamentalt.
En anden lære er læren om misbrugte lærestykker! Tvivl om klogskaben i den amerikanske Vietnampolitik blev fejet af bordet med henvisning til de eftergivende demokratier i München, som igen var et forsøg på at undgå en gentagelse af katastrofen i sommeren 1914.

Historien om Vietnamkrigen kan bruges og misbruges på mange måder. 